\begin{tabular}{|c|c|}
\hline 昭和 36 年 & $\begin{array}{l}\text { 大空洞充填用採土開始 } \\
\text { 鉄板坑开使用的始 }\end{array}$ \\
\hline 昭和37年 & 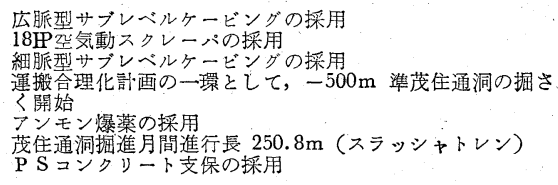 \\
\hline 昭和38年 & 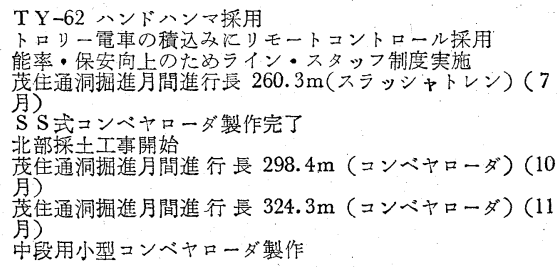 \\
\hline
\end{tabular}

\begin{tabular}{|c|c|}
\hline 昭和39年 & 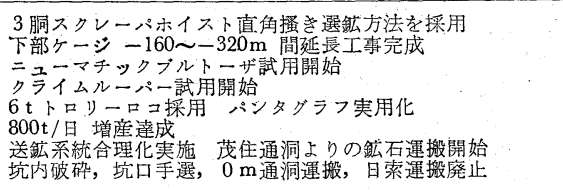 \\
\hline 昭和 40 年 & 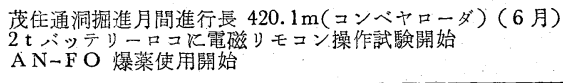 \\
\hline 昭和 41 年 & 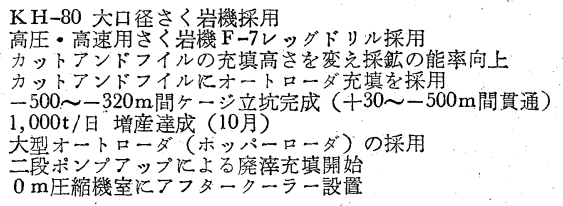 \\
\hline
\end{tabular}

昭和42年 $3 \mathrm{t}$ バッテリーロコの採用により $2 \mathrm{t} よ り 3 \mathrm{t}$ 強化

\title{
神岡鉱山杤洞坑
}

\section{Tochibora Deposits of Kamioka Mine}

\section{1. 緒}

言

位 置 : 杤洞坑は岐阜県の北端，吉城郡神岡町に位置 する神岡鉱山の主要採掘場である。交通の便は国鉄高山 本線猪谷駅より国鉄神岡線にて約 30 分で当町に至り，更 にバスで40分の所に杤洞坑がある。また国鉄高山駅，古 川駅，猪谷駅より当町まで定期バスの運行がある。

沿：革：当坑発見の年代は，およそ 1,200 年前，すな わち養老の時代と伝えられているが，開発の時期は戦国 末期, 弘治年間で, 開発の祖といわれている和佐保所兵 衛によつてなされたものである。往時は銀, 銅, 鉛を主 に産した模様で, 海抜 $1,200 \mathrm{~m}$ (二十五山) 付近の露頭 部には多数の旧坑や，カラミをみることができる。その 後, 明治19年より三井の所有となり, 本格的な開発に着 手し, 昭和 25 年三井鉱山から分離, 三井金属として独立 したので，三井金属鉱業神岡鉱業所杤洞坑として，今日 に至つている。

現 状（第 $1 ， 2$ 表参照, 昭和 42 年 3 月実績)
第 1 表 粗鉱量と出鉱品位

\begin{tabular}{c|c|c|c|c}
\hline $\begin{array}{c}\text { 粗鉱量 } \\
(\mathrm{t})\end{array}$ & \multicolumn{2}{|c|}{ 品 } & \multicolumn{2}{|c}{ 位 } \\
\cline { 2 - 5 } & $\mathrm{Au}$ & $\mathrm{Ag}$ & $\mathrm{pb}$ & $\mathrm{Zn}$ \\
\hline 109,775 & & $\begin{array}{r}\mathrm{g} / \mathrm{t} \\
\mathrm{n}\end{array}$ & 0.37 & 3.83 \\
\hline
\end{tabular}

* 三井金属釯業株式会社神岡釯業所

\author{
正会員東尚 七* \\ Naoshichi HIGASHI
}

\section{$2 \cdot 1$ 地 質}

神岡鉱山は，いわゆる「飛驒変成帯」の中央部に位置 しており, 主に飛驒片麻岩類と船津花崗岩, 下之本花菵 岩などの古期深成岩類が分布しているが，北および東方 にはこれらを基盤として中生代手取統が堆積し，さらに 以上の諸岩を中生代末の岩脈が貫いている。鉱床は主 に，飛驒片麻岩系中の結晶質石灰岩が中生代末の火成活 動に伴なつて鉱化された「高温交代鉣床」で，当地域の 地史を「鉱床形成歴史」として要約するとつぎのように なる。

（1）飛驒片麻岩系（鉱床胚胎の場）の生成：主とし てゴトランド紀（約 3.5 億年前）以前に堆積した地層が 古生代末から中生代初め（1.9～1. 5億年前）の広域変成 作用によつて片麻岩となつたもので，日本最古の岩類と 考えられている。原堆積成分の差異に応じ，黒雲母角閃 石片麻岩, 角閃岩, 透輝石片麻岩など各種の片麻岩が形 成されたが，とくに含黒鉛結晶質石灰岩に富んでおり， 恵まれた「鉙床罘胎の場」を形成した。

（2）船津および下之本花崗岩類の迸入：変成作用に 続いて起つた深成作用の所産と考えられ, 飛驒片麻岩帯 の外側にとりをくように分布し，境界部にばじしば眼 球片麻岩を形成している。

（3）中生代手取統の堆積とその後の徨上運動による 裂カ系（鉱液の通路）の開裂：ジュラ紀末から中部白亜 


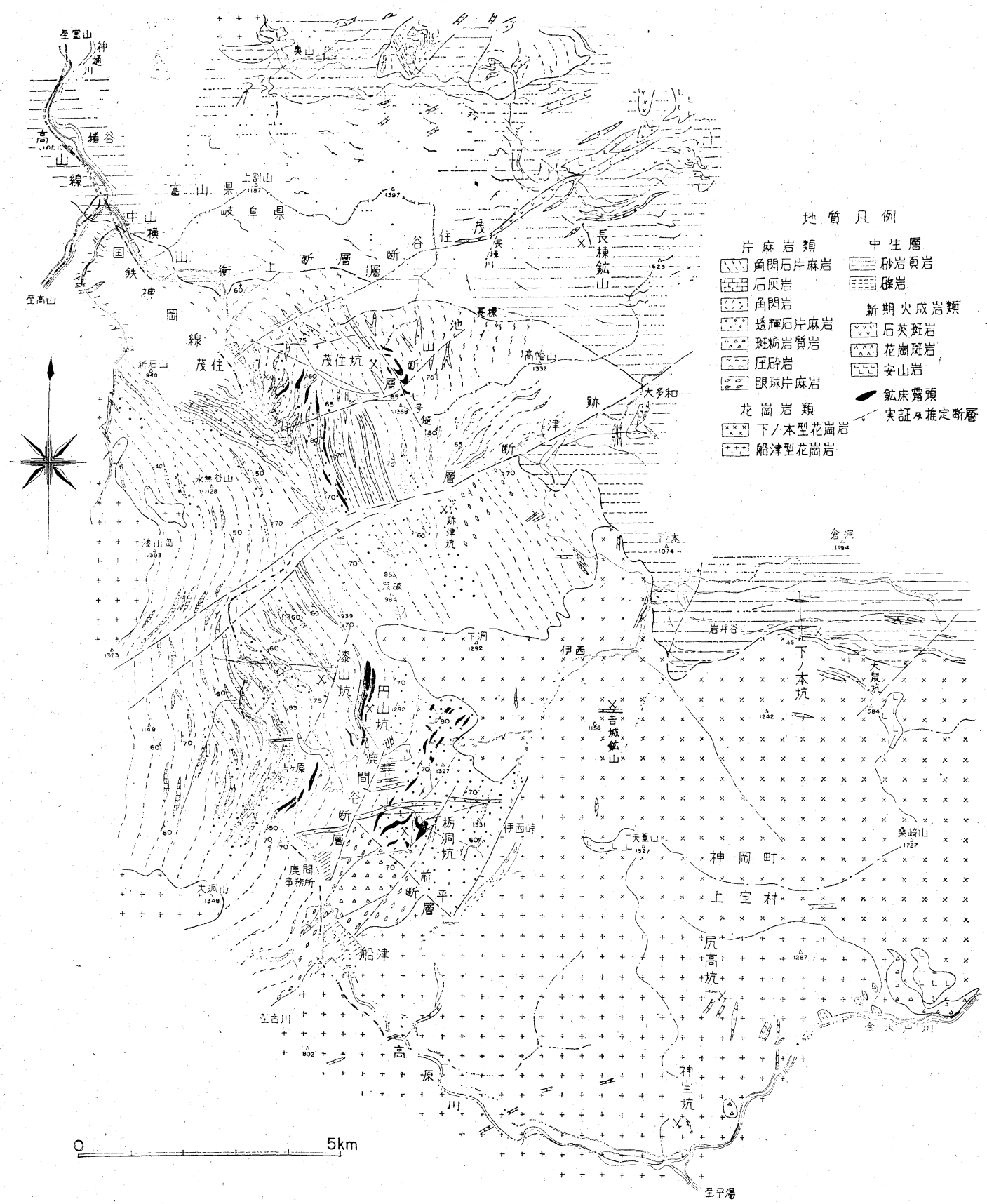

第1図 神岡鉱山付近地質図

紀にかけ一, 浅海〜淡水性の碟石, 砂岩, 頁岩累層が堆 積したが，下部白亜紀の衝上運動によ，茂住北部から下 之本にかけて基盤の片麻岩, 花崗岩が本累層の上に乗り 上げた。この衝上運動に関連して多くの断層, 裂力が発 達し，「鉣液の通路」を形成した。

（4）中生代白亜紀末の火成活動之鉱床の生成：上部 衝上運動に引続いて, 花崗斑岩, 石英斑岩, 石英玢岩な どの岩脈が貫入した。この火成活動が鉙液を供給し，主
に片麻岩系中の石灰岩，時には裂力そのものが，「鉱液 定着の場」となつて鉱床を生成した。

\section{$2 \cdot 2$ 鉱 床}

杤洞坑が現在開発中の鉱床は，杤洞鉣床群と円山鉱床 群であるが，ともに片麻岩系中の石灰岩を交代した鉛・ 亜鉛スカルン鉱床を主体にしており，鉱床となつた石灰 岩の規模および複雑な裮曲形式および鉱液の通路となつ た裂力群との交錯形式に応じて大さまざまな塊状ない 


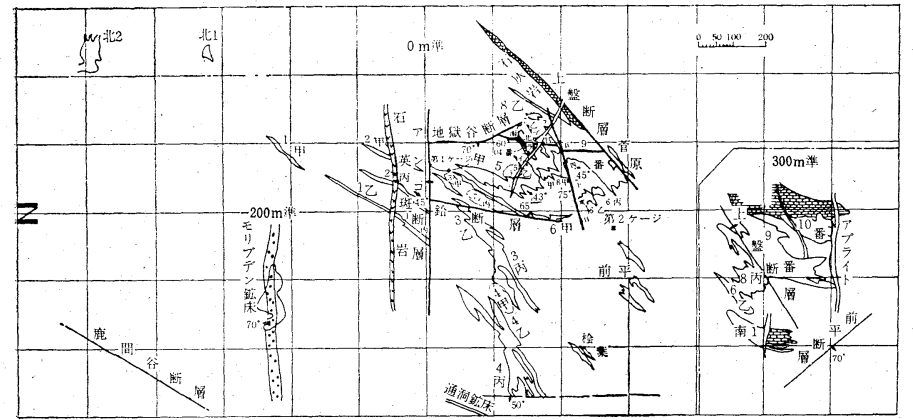

第2図栃洞坑鉱床配置図

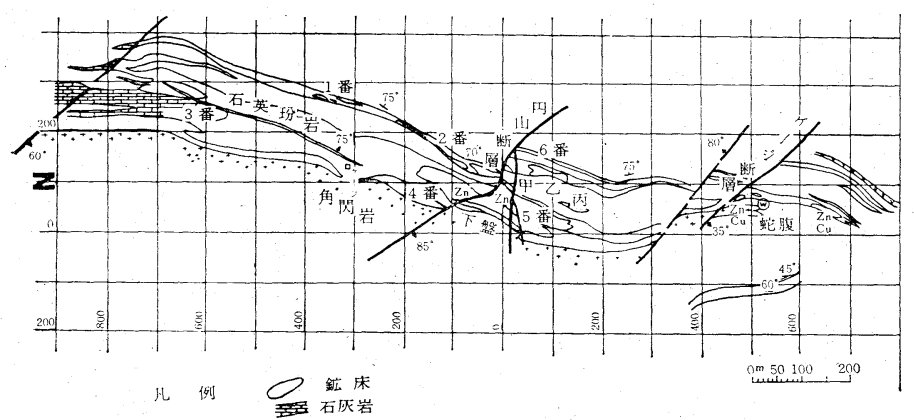

第3 図 円山坑鉱床配置図 $(0 \mathrm{~m}$ 準)

し層状鉣体つ集合となつている。

（1）栃洞鉱床群: 南北 $1,500 \mathrm{~m}$, 東西 $1,000 \mathrm{~m}$ にわる 区域に大小50有余の鉱体が存在するが，これらは NE$\mathrm{SW}$ 方向を軸とし S Wへ $35^{\circ} \sim 50^{\circ}$ 傾くM字型の複合向斜 構造をなす 9 層の石灰岩を交代したもので, 激しい引摺 褔曲のため膨縮著しい不規則塊状を呈する。各釷体の走 向および傾斜は褶曲の部位により異なるが，概ねの走向 NEないしNS, 南東傾斜を示し，落しは褔曲のそれと ほぼ同じく $35^{\circ} \sim 45^{\circ} \mathrm{S}$ となつている。最大の鉱体は 9 番 鉱床で幅 $60 \mathrm{~m}$, 延長 $250 \mathrm{~m}$, 深さ $500 \mathrm{~m}$ 以上の規模に達 する。

大部分の鉱石は「杢地」と称する高温交代性のスカル ン鉱であるが，一部に「白地」と俗称する中熱水交代型 の鈗石む存在する。「本地鉱」は扊鉄輝石を主とし緑策 石，柘榴石などを随伴するスカルン中に閃亜鉛鉱・含銀 方鉛鉱, 他の鉱石・鉱物が散在する鉱石で, 亜鉛品位 $4 \sim 6$ \%程度が普通である。

「白地鉱」法石英，方解石などの白色脈石からなる高 品位鉱で鉛・亜鉛合せて15 25\%程度の品位を示すが， 一般に小規模で，強い裂力規制をらけて不規則な形とな つている。「白地鉱」は一部「圭地鉱」自体を交代して おりその鉱化の時期は少なくとも「圭地鉱」生成後と も考えられる。

（2）円山鉱床群: 杤洞坑の北方 $2 \mathrm{~km}$ にあり, 走向
$\mathrm{NS}$, 傾斜 $60^{\circ} \sim 70^{\circ} \mathrm{E}$, 落し5 $0^{\circ} \mathrm{S}$ 党 示寸 2 層の大石灰岩を交代して10余 の「杢地」鉱体があり, 最大の 5 番 鉱床は幅 $50 \mathrm{~m}$, 延長 $300 \mathrm{~m}$, 深さ $400 \mathrm{~m}$ 以上の規模を有する。円山鉱床群の 、特長は, スカルンの規模は極めて大 きいのに，鉱体が円山断層周辺に局 在することで, 石死岩構造が単調で あることに一因ありと考えられる。

鉱石はすべて「本地鉱」である が，杤洞のそれに比べ柘榴石スカル ンが多く, 亜鉛品位6 8\% で若干高 いが鉛品位は低く，かつ地表付近の 酸化変質が極めて著しい。

（3）.鉱石の帯状分布 : 杤洞・ 円 山鉱床群は元来典型的な鉛・亜鉛鉱 床とされていたが，開発の進捗に伴 なつて栃洞一円山一漆山に一連の鉱 石帯状分布の存在が明らかになつて きた。これは，栃洞・ 円山・漆山 の各鉱床群が，ひとつの鉱液源より 生成されたことを示唆し，その解明 は鉱床の生成機構, 鉱化圈の形, 規 模, 鉱質変化を予測する重要な鍵になると考えられる。 今までに判明したところでは，枋洞，円山の中間に貫入 した石英斑岩, 含モリブデン花崗斑岩岩脈群を中心に第 4 図のような水平的な帯状分布がある。

\section{3. 採 掘法}

\section{3・1 採掘法の変せんおよびその採用の理由}

(第 3 表参照)

\section{$3 \cdot 2$ 現在の採掘法の種類および説明}

(第 4 表参照)

\section{3 . 3 主な採掘法}

(第 $5,6,7,8,9$ 図参照)

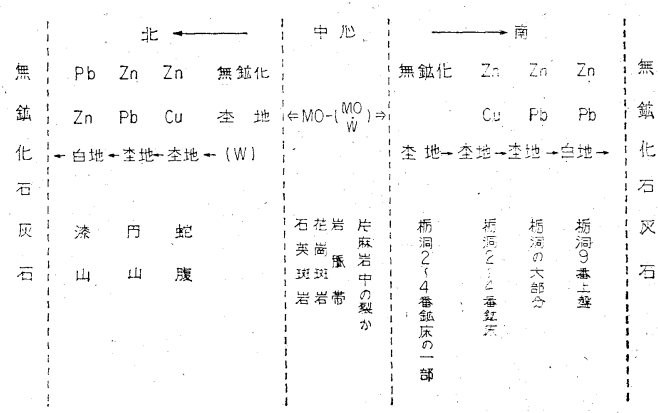

第 4 図 
東：神岡鉱山栃洞坑

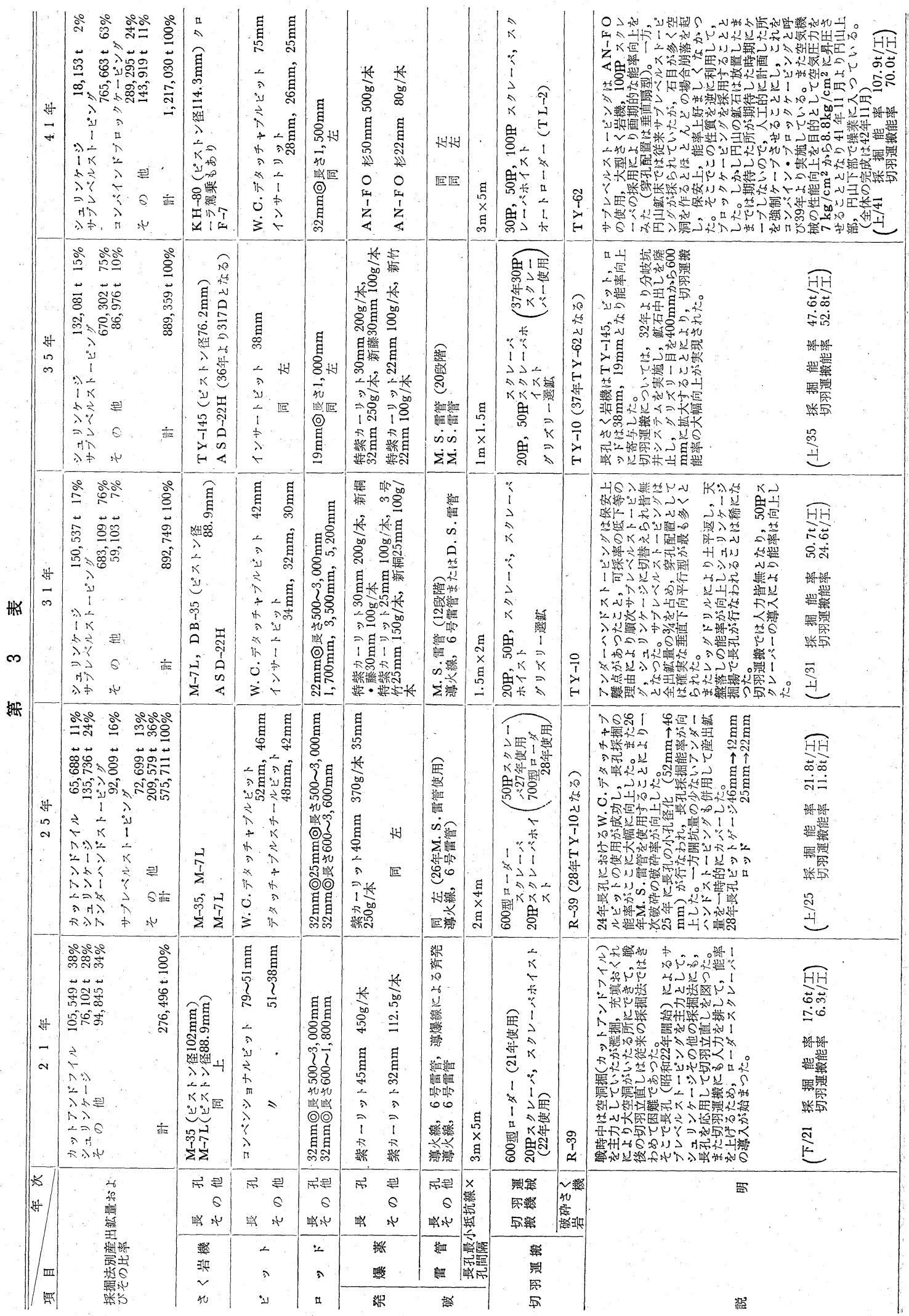


塊状鉣床
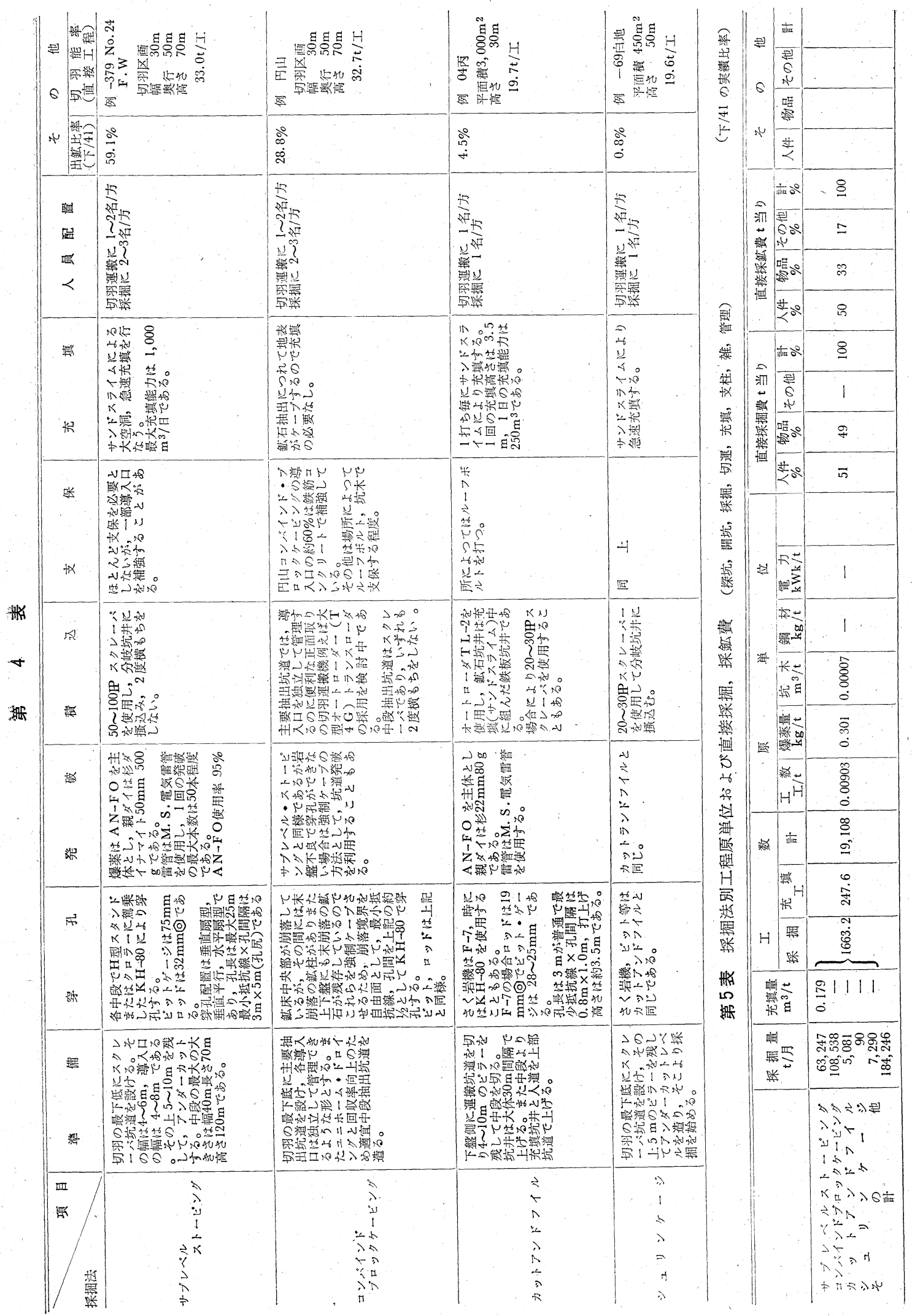


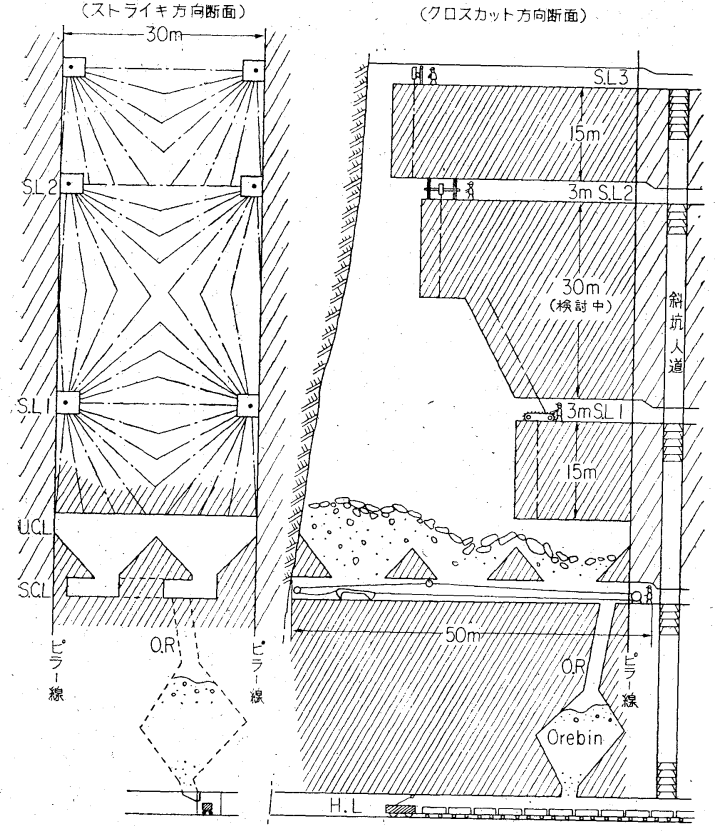

第 5 図 サブレベルストーピング法模式図

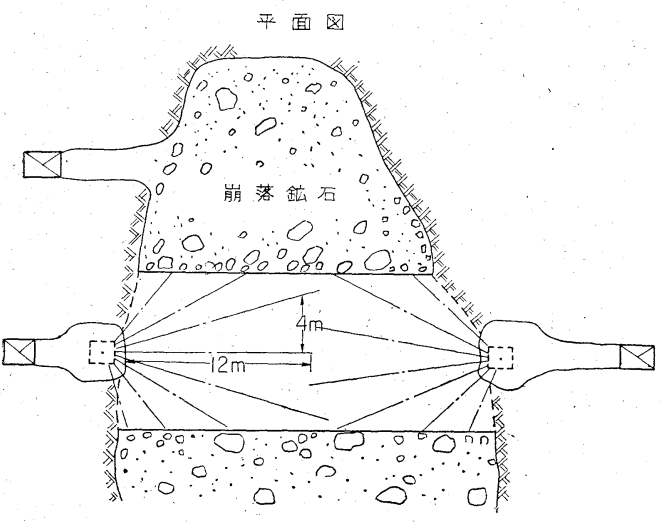

断面図

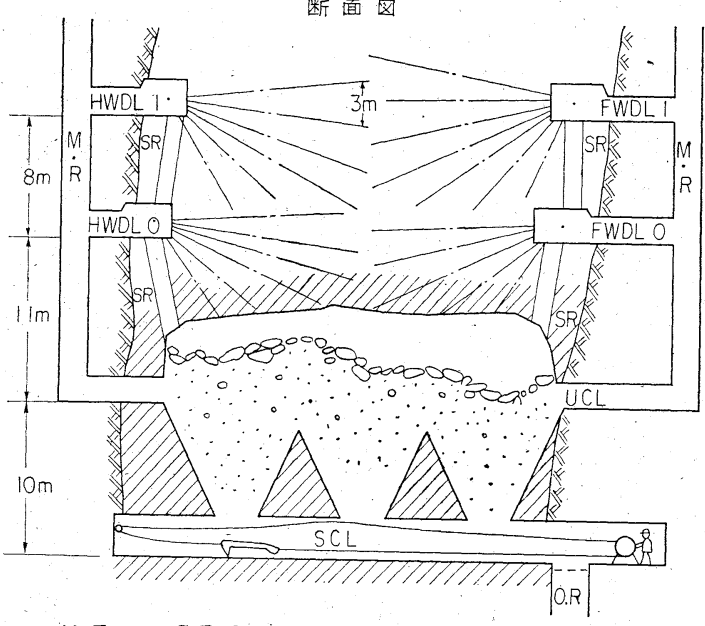

第7図 C BC法に掉いて長孔シニッンケーシ を使つた強制発破の一例
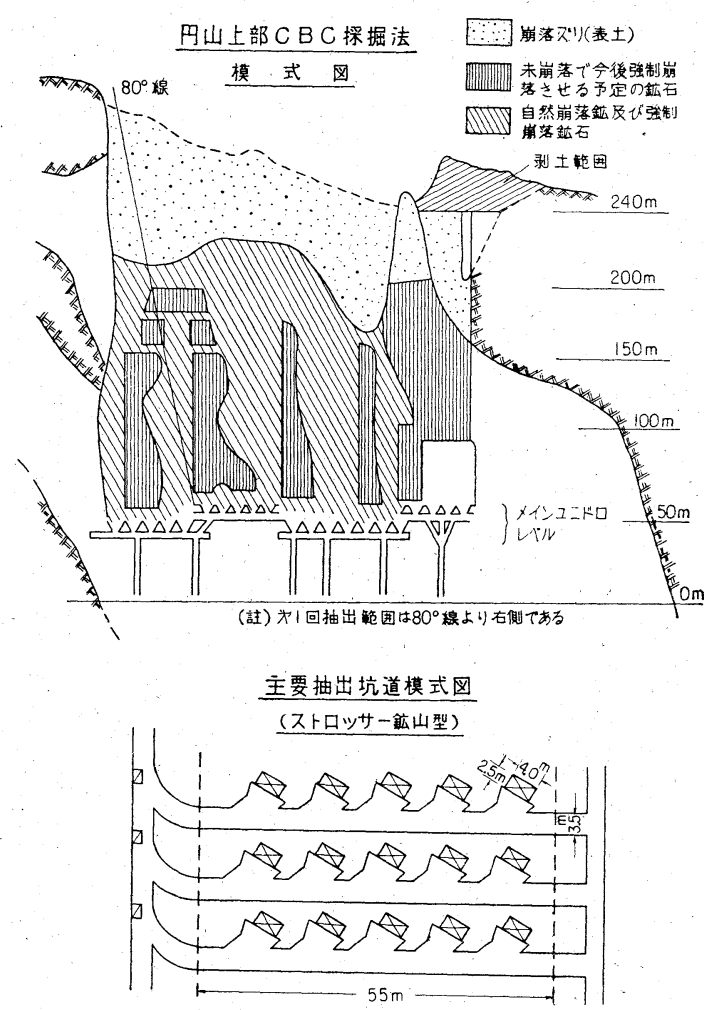

第6 図 円山上部C B C 採掘法模式図

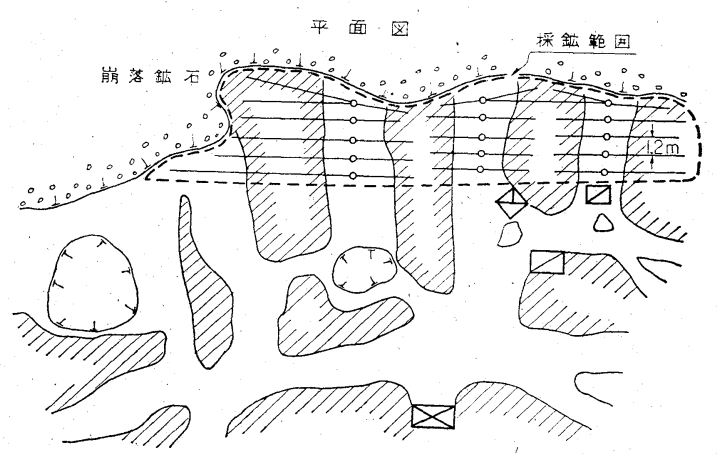

断面园 採銶䭒围

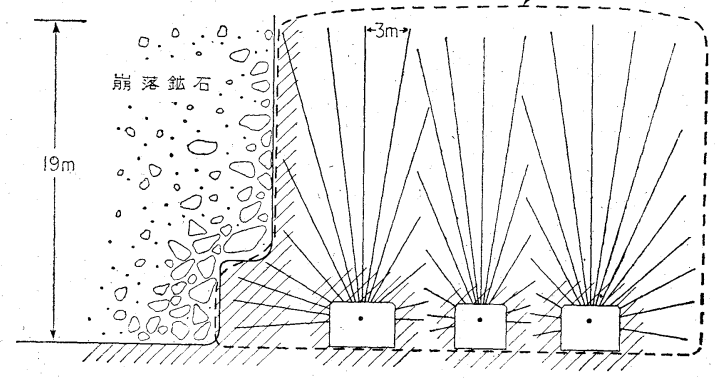

第8図 CBC法に扗いて崩落境界面を自由面 そした強制発破の一例 


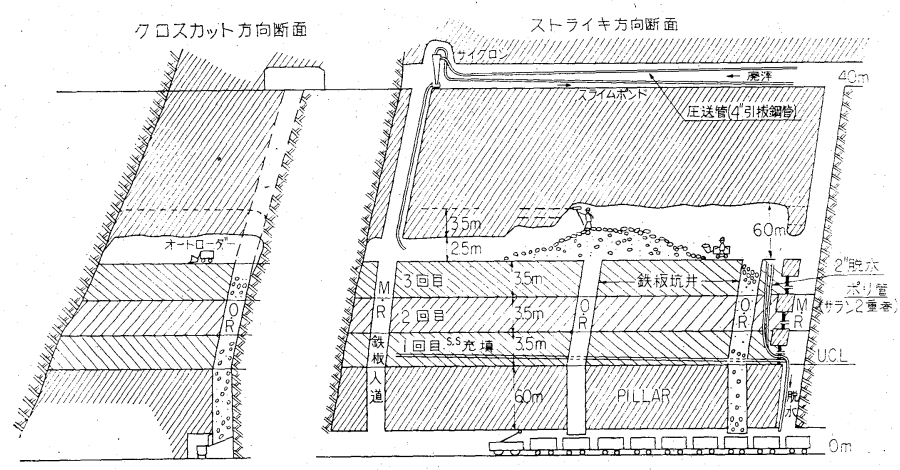

注）据場の一端よりサンドスライムを投入して上澄水を掘場の他端飞集めそこで脱水する。

第 9 図 サンドスライム充填によるカットアンドフィル模式図 (S.S.充填)

\section{4. 運}

搬

\section{1 鉱 石}

採掘された鉱石は，切羽運搬，鉱 石坑井, 岡出の 3 段階によつて運搬 される。

（1）切羽運搬 約90\%をスク レーパによつて処理し，つぎに述べ る各項の改善により, 大幅の能率向 上が実現した。（第 8 表参照）

a) スレクーパ坑道の幅を, 2 $4 \mathrm{~m}$ より $4 \sim 6 \mathrm{~m}$, 高さを $2.5 \sim 3.5 \mathrm{~m}$,

第 6 表 採掘法別出鉱量および切羽数

\begin{tabular}{|c|c|c|c|}
\hline 採掘法の種類 & $\begin{array}{c}\text { 出釷量 } \\
(\mathrm{t})\end{array}$ & $\begin{array}{c}\text { 出鉱比率 } \\
(\%)\end{array}$ & 切 羽 数 \\
\hline 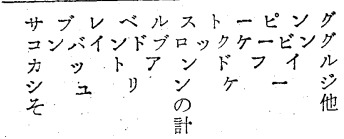 & $\begin{array}{r}66,399 \\
25,671 \\
4,372 \\
90 \\
6,138 \\
102,670\end{array}$ & $\begin{array}{r}64.7 \\
2.0 \\
4.2 \\
0.1 \\
6.0 \\
100\end{array}$ & $\begin{array}{r}15 \\
9 \\
5 \\
1 \\
4 \\
34\end{array}$ \\
\hline
\end{tabular}

第 7 表 開探鉱出鉱量抢よび試錐延長

\begin{tabular}{|c|c|c|c|c|c|c|}
\hline & \multirow{2}{*}{ 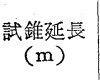 } & \multirow{2}{*}{$\begin{array}{c}\text { 探鉱娫長 } \\
(\mathrm{m})\end{array}$} & 出 & \multirow{2}{*}{$\frac{\text { 釯 }}{\text { 採 }}$} & \multirow{2}{*}{$\begin{array}{l}\text { 量 } \\
\text { 釷厸 }\end{array}$} & \multirow{2}{*}{$\frac{(\mathrm{t})}{\text { 訫 }}$} \\
\hline & & & 開 探 鉱 & & & \\
\hline 3 月 & $2,738.05$ & 473.4 & 6,363 & 102 & & 109,033 \\
\hline
\end{tabular}

第 8 表 切羽運搬機械機種別推移表

\begin{tabular}{|c|c|c|c|c|c|c|c|}
\hline 機 & 種 & 項目 & 単位 & 上/31 & 上/35 & 上/41 & 下/41 \\
\hline z & $100 \mathbb{P}$ & $\begin{array}{l}\text { 筷量 } \\
\text { 工 } \\
\text { 能率 } \\
\text { 比率 }\end{array}$ & $\underset{\mathrm{t} / \mathrm{I}}{\mathrm{t}}$ & & & \begin{tabular}{r|r|}
136,023 \\
$1,324.2$ \\
102.7 \\
23.7
\end{tabular} & $\begin{array}{r}174,503 \\
1,287.2 \\
135.6 \\
30.4\end{array}$ \\
\hline " & $50 \boxplus$ & $\begin{array}{l}\text { 钠量 } \\
\text { 数 } \\
\text { 能率 } \\
\text { 比率 }\end{array}$ & $\underset{t / I}{\mathrm{t}}$ & \begin{tabular}{r|r}
95,183 \\
$2,583.0$ \\
36.8 \\
23.6
\end{tabular} & $\begin{array}{c}276,423 \\
4,190.5 \\
66.1 \\
66.2\end{array}$ & $\begin{array}{r}253,866 \\
3,119.8 \\
81.4 \\
44.2\end{array}$ & $\begin{array}{r}209,973 \\
2,314.8 \\
91.0 \\
36.6\end{array}$ \\
\hline 1 & $30 \mathrm{PP}$ & $\begin{array}{l}\text { 臸量 } \\
\text { 工数 } \\
\text { 能率 } \\
\text { 比率 }\end{array}$ & 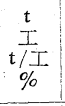 & & & $\begin{array}{r}110,781 \\
1,489.8 \\
74.3 \\
19.3\end{array}$ & $\begin{array}{r}89,420 \\
1,338.5 \\
66.9 \\
15.6\end{array}$ \\
\hline ハ̊ & $20 \mathbb{P}$ 以下 & \begin{tabular}{l|} 
鉱量 \\
工数 \\
態率 \\
比率
\end{tabular} & $\begin{array}{c}t \\
I \\
t / I \\
\%\end{array}$ & $\begin{array}{r}125,774 \\
4,360.9 \\
\text { その他 } 439 \\
28.8 \\
31.2\end{array}$ & $\begin{array}{r}85,552 \\
2,095.1 \\
42.3 \\
20.6\end{array}$ & $\begin{array}{r}39,329 \\
738.7 \\
53.2 \\
6.8\end{array}$ & $\begin{array}{r}32,072 \\
514.2 \\
62.4 \\
5.6\end{array}$ \\
\hline ㅁ & オートロー & $\begin{array}{l}\text { 鉱量 } \\
\text { 能数 } \\
\text { 態率 } \\
\text { 比率 }\end{array}$ & $\begin{array}{c}\mathrm{t} \\
\mathrm{I} \\
\mathrm{t} / \mathrm{I} \\
\%\end{array}$ & & & $\begin{array}{r}20,549 \\
551.7 \\
37.2 \\
3.6\end{array}$ & $\begin{array}{r}23,298 \\
588.4 \\
39.6 \\
4.1\end{array}$ \\
\hline ダ & 口 $-\not ゙$ & $\begin{array}{l}\text { 金量 } \\
\text { 数 } \\
\text { 能率 } \\
\text { 比率 }\end{array}$ & $\begin{array}{c}\mathrm{t} \\
\mathrm{I} / \mathrm{I} \\
\%\end{array}$ & $\begin{array}{r}61,111 \\
2,328.3 \\
26.2 \\
15.2\end{array}$ & $\begin{array}{r}11,317 \\
471.3 \\
24.0 \\
2.7\end{array}$ & $\begin{array}{r}9,585 \\
271.2 \\
35.3 \\
1.7\end{array}$ & $\begin{array}{r}18,956 \\
565.1 \\
33.5 \\
3.3\end{array}$ \\
\hline $\begin{array}{l}y \\
y \\
x \\
y \\
y\end{array}$ & グリズリ & $\begin{array}{l}\text { 鉣量 } \\
\text { 工数 } \\
\text { 態率 } \\
\text { 比率 }\end{array}$ & $\underset{\%}{t} \stackrel{t}{T}$ & $\begin{array}{r}118,302 \\
2,838.1 \\
41.7 \\
29.4\end{array}$ & $\begin{array}{r}30,989 \\
620.0 \\
56.4 \\
7.5\end{array}$ & $\begin{array}{r}4,247 \\
76.4 \\
55.6 \\
0.7 \\
\end{array}$ & $\begin{array}{r}23,032 \\
396.1 \\
58.1 \\
4.0 \\
\end{array}$ \\
\hline 中 & & $\begin{array}{l}\text { 鉱量 } \\
\text { 薮 } \\
\text { 態率 } \\
\text { 比 }\end{array}$ & $\begin{array}{c}t \\
t / I \\
\%\end{array}$ & $\mid \begin{array}{r}2,344 \\
(220,575) \\
2,731.6 \\
80.7 \\
0.6\end{array}$ & $\begin{array}{r}10,604 \\
(17,072) \\
480.4 \\
35.5 \\
2.6\end{array}$ & $\begin{array}{r}182 \\
51,007) \\
60.7 \\
80.9 \\
-\end{array}$ & $\begin{array}{r}2,392 \\
(43,150) \\
594.2 \\
76.6 \\
0.4\end{array}$ \\
\hline 合 & 計 & $\begin{array}{l}\text { 鉱量 } \\
\text { 率 } \\
\text { 能率 } \\
\text { 比率 }\end{array}$ & $\underset{\mathrm{t} / \mathrm{I}}{\mathrm{t}}$ & $\begin{array}{r}402,714 \\
15,280.9 \\
26.4 \\
100\end{array}$ & $\begin{array}{r}414,885 \\
7,857.3 \\
52.8 \\
100\end{array}$ & $\begin{array}{r}574,562 \\
8,202.5 \\
70.0 \\
100\end{array}$ & $\begin{array}{r}573,646 \\
7,598.5 \\
75.5 \\
100\end{array}$ \\
\hline
\end{tabular}

導入口の幅を $2 \sim 4 \mathrm{~m} よ り 4 \sim 8 \mathrm{~m}$ とし，導入口もましの時 間を短縮し，一もましの鉣量を増大させた。

b) スクレーパを大型化し， $(50 \rightarrow 100 \mathrm{P} ）$ 分岐坑井方 式を実施して小割発破を少なくするとともに，2次中出 しを省いた。

c） AN-FO と大型さく岩機を採用して, 採掘の破 砕度を向上させた。

（2）鉱石坑井 当坑鉱石運搬の特色は, 通洞地並 以上の採掘であり，重力運搬で 2 度横持ちをしないこと である。すなわち主要運搬坑道より上げられた 1 本の主 要坑井は, 途中で数本に分岐し, 各切羽のスクレーパ坑 道に達している。これにより 2 次中出しを省き, 開坑量 を節減し，集約運鉱の実をあげている。

(3) 岡 出 前述の鉱石坑井 (分岐坑井) の貯鉱

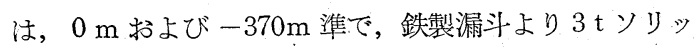
ド鉱車に積込まれ， $4 \mathrm{t} ， 8 \mathrm{t}$ トロリ一電車によつて，そ れぞれ杤洞選鉣場, 鹿間選鉱場まで運ばれる。岡出能率 も坑井管理, 穦込漏斗の改善により, 下表のような上昇 をみせている。

第 9 表

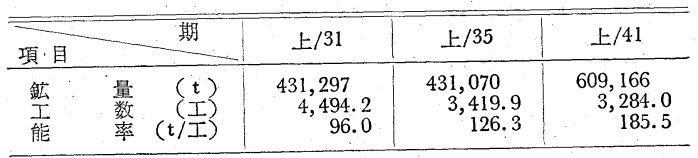

（4）運搬合理化計画 現在, 鉱車の大型化, 大型 クラッシャの坑内設置, 長尺コンベヤの採用等の運搬合 理化を 43 年 3 月完成の予定で実施しているが，これの完 成の曉には，杤洞坑の $4,400 \mathrm{t} /$ 日増産合理化計画 (44 年 完成）とあいまつて, 坑内作業全体の能率の大幅向上が 実現される。（第10図参照）

\section{$4 \cdot 2$ ズリ}

探開坑で発生するズリは，当該作業者がズリ発生源の レベル以下の採掘跡の空洞に直接投入することを原則と

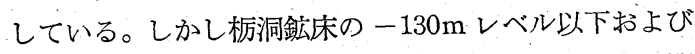
円山鉱床の $0 \mathrm{~m}$ レベル以下のズリは, $-370 \sim-130 \mathrm{~m}$ 間 


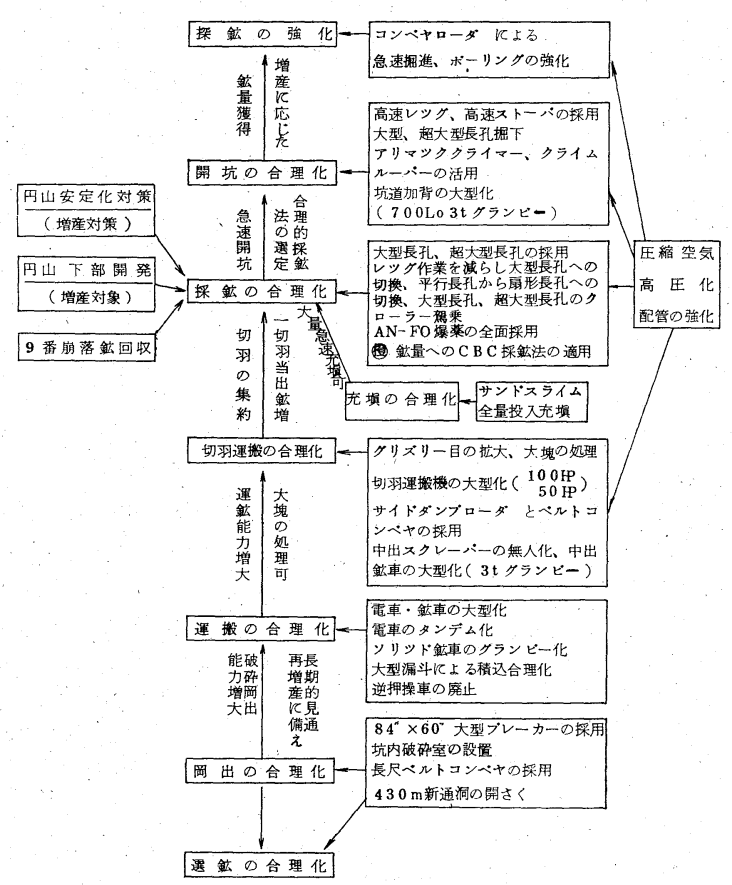

第10図 栃洞坑 4,400t/日 増産合理化構想

立坑スキップにより，- $-130 \mathrm{~m}$ レベルに巻き上げ，スキ ップ近傍の空洞に直投入している。

なお，ズリ巻上用スキッブの運転は，従来 $-130 \mathrm{~m}$ 機 械室に運転員 1 名， $-370 \mathrm{~m}$ スキップ底に積方 1 名の計 2 名で行なつていたが，現在はスキップ底の積方 1 名が テレビで監視しながら，リモコンで巻上機運転を行なつ ている。

\section{3 人員・資材}

$0 \mathrm{~m}$ おび-370m レベル主要通洞は, トロリ一電車 により，人車または資材列車が運転されており，坑内各 レベル間の連絡には，杤洞上部ケージ，杤洞下部ケ一 ジ, 円山上部ケージ，円山下部ケージが運転されてい る。このケージの各プラットでの乗降は，テレビにより 運転員または棹取員が監視できるようになつている。現 在円山上部ケージ, 円山下部ケージには, さらに各プラ ットからの乗降依頼記憶信号装置を設備し，専任の棹取 員を配置していない。

\section{5. 通気, 排水, 照明, 保安, その他}

\section{$5 \cdot 1$ 通 気}

（1）栃 洞：主して，自然通気によつているが，0 $\mathrm{m}$ 準以下は， 5 月 10 月間， $-370 \mathrm{~m}$ 主要運搬坑道に設 置された $50 \mathrm{H}$ 扇風機によつて強制通気を行なつている。

（2） 円 山： $+150 \mathrm{~m}$ 準に $50 \mathrm{PP}$ 扇風機を設置して, 年間を通じ強制通風を行なつている。

\begin{tabular}{|c|c|c|c|c|c|c|c|}
\hline 項 & 目 & 馬 & 力 $(\mathbb{P})$ & 型 & 式 & $\begin{array}{l}\text { 風水柱 } \mathrm{Im} \text { ) } \\
\text { 原 }\end{array}$ & $\begin{array}{l}\text { 風 } \\
(\mathrm{m} 3 / \mathrm{min})\end{array}$ \\
\hline 杤洞 & 風機 & & $\begin{array}{l}50 \\
50\end{array}$ & $\begin{array}{l}\text { 軸流了 } \\
\text { 流子 }\end{array}$ & $\begin{array}{l}\text { プ้ } \\
\text { รンั }\end{array}$ & $\begin{array}{l}50 \\
40\end{array}$ & $\begin{array}{l}3,000 \\
2,400\end{array}$ \\
\hline
\end{tabular}

なお， $\mathrm{AN}-\mathrm{FO}$ 爆薬の採用，切羽の進展に伴なつて 必要に応じて $5 \mathrm{H}$ 局部扇風機を用いている。

\section{$5 \cdot 2$ 排 水}

スキップ底およびケージ立坑底の排水以外；すべて自 然排水であり，選鉱および硫酸工場の用水として有効利 用している。

\begin{tabular}{l|c|c|c|c}
\hline 項 & 目 & 水 量 $\mathrm{t} /$ 日 & $\mathrm{pH}$ & 濁 \\
\hline $0 \mathrm{~m}$ & 隻 & 7,200 & 7.4 & 70 \\
$-370 \mathrm{~m}$ & 潐 & 14,000 & 7.3 & 50 \\
\hline
\end{tabular}

\section{$5 \cdot 3$ 照 明}

主要坑道は螢光灯, 切羽入通じる坑道, 探鉱坑道は普 通電灯，作業場はアイランプまたは普通電灯と，ほぼ完 全な照明が行なわれ，作業者は常にアルカリ電池のキャ ップランプを携帯している。

\section{4 保 安}

保安の 3 原則，すなわち “保安は計画から”“保安は 機先を制し”“保安は「みんなの目」から”の3 項目を かかげて，管理者，第一線監督者，作業者，それぞれの 指標とし, 保安委員会, 保安常会, 災害検討会, 保安教 育，無災害時間達成運動「みんなの目」等具体的な活動 を積極的に行なつている。またライン・スタッフ制度を強 化し, ラインの監督者の 1 切羽当り滞在時間を長くし卒 先して保安の確保にあたり，これをスタッフが補つて勧 告する有機的な組織としている。災害件数については次 表のように減少している。

\begin{tabular}{|c|c|c|c|c|c|c|}
\hline 項 目 & 昭37年 & 昭38年 & 昭39年 & 昭 40 年 & 昭 41 年 & $\begin{array}{l}\text { 昭42年 } 6 \text { 月 } \\
\text { まで }\end{array}$ \\
\hline 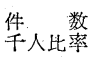 & $\begin{array}{r}44 \\
0.22\end{array}$ & $\begin{array}{r}37 \\
0.13\end{array}$ & $\begin{array}{r}32 \\
0.18\end{array}$ & $\begin{array}{r}23 \\
0.13\end{array}$ & $\begin{array}{r}14 \\
0.08\end{array}$ & $\begin{array}{r}5 \\
0.06\end{array}$ \\
\hline
\end{tabular}

\section{6. 問題点と将来の計画}

\section{$6 \cdot 1$ 問題点}

1）円山C B C法におけるズリ混入率および回収率

2）小規模釷床および残存鉱柱の高能率採鉱

3）支柱修綣および主体作業に付随する雑作業の合理 化

\section{$6 \cdot 2$ 将来の計画}

技術革新は現在まで大型化，急速化，高圧化を目標と し，ブロック・ケービング採掘法の採用と運搬合理化等 を進めてきたが，さらに自動化，機械の一人多数台持 ち，集約化，支柱の合理化等を推進する計画であり，一 例をあげると。

1）長孔採掘における 1 マン 2 ドリルの実現

2）大型切羽運搬機械として，トランスローダ（ディ 一ゼルエンジン)，オートローダの採用 
3）主要運搬のダンデム運転

4）長孔による切上の合理化（25m位まで）

5）積込・運搬のリモート・コントロール

6) ケージ運転の無人化

7）坑内総合能率 $15 \mathrm{t} /$ 人 ・方の達成(現在 $7.5 \mathrm{t} /$ 人・方) 等である。

\section{7. 過去 10 年間の年間粗釷量, 平均品位 および能率（坑内，全山）の推移}

（第10表・第11図）

\section{第10表}

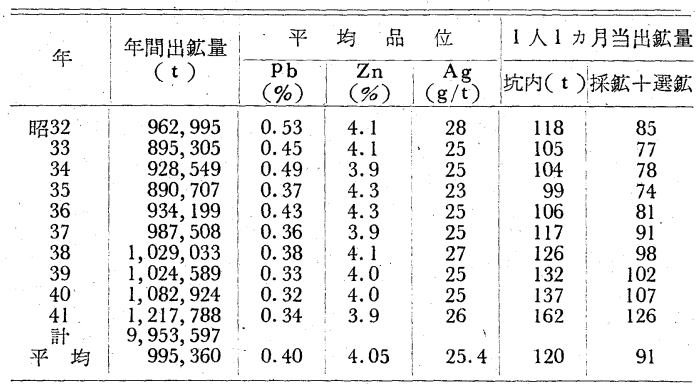

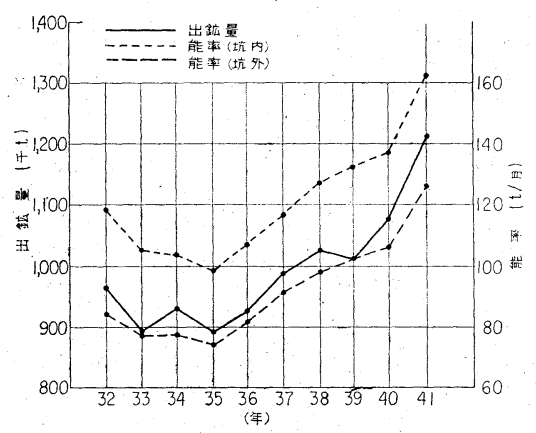

第11図
竜
第11表 技術的変遷年表

\begin{tabular}{|c|c|}
\hline 年次 & 事 \\
\hline $\begin{array}{c}\text { 昭和 } \\
32\end{array}$ & 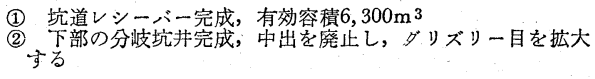 \\
\hline 33 & (1) 空洞充填を開始, ムカデ鉱車を実用化 \\
\hline 34 & 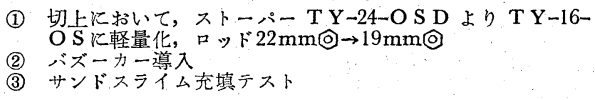 \\
\hline 35 & 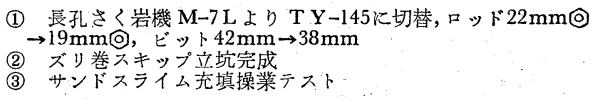 \\
\hline 36 & $\begin{array}{l}\text { (1) レックドリルA S D-22より } 317 \mathrm{D} \text { 切替, ロッド } 22 \mathrm{~mm} \text { (0) } \\
\rightarrow 19 \mathrm{~mm} \text { (2) } \\
\text { (2) サンドスライム充填操業に入る } \\
\text { (3). } 18 \mathrm{P} \text { エアーホイスト採用 }\end{array}$ \\
\hline 37 & 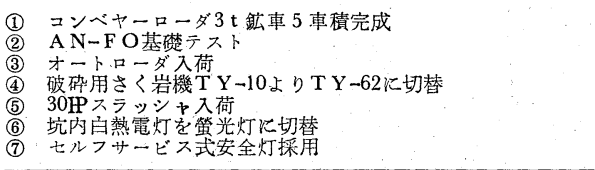 \\
\hline 38 & $\begin{array}{l}\text { (1) アリマッククライマーによる切上開始 } \\
\text { (2) 掘進合理化活動開始 }\end{array}$ \\
\hline 39 & 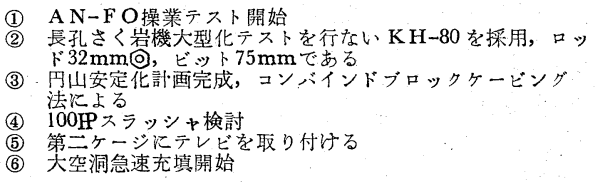 \\
\hline 40 & 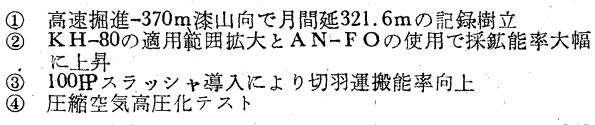 \\
\hline 41 & 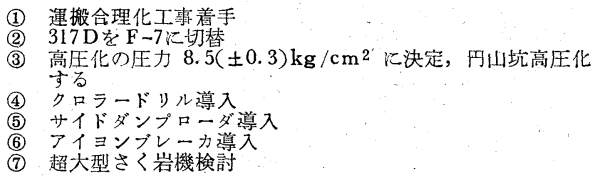 \\
\hline
\end{tabular}

\section{Nakatatsu Mine}

鉱

U1

\section{1. 緒}

\section{言}

位置 : 中竜鉱山は福井県九頭竜川の上流に位置し，その 鉣区は同県大野郡和泉村，西谷村，および大野市にわた る。

沿革 : 古く寛元年間に発見されたといわれ，幾多の盛 衰の過程を経て, 明治の初期には一時外国人の手で探鉱

* 日本亜鈴鉱業株式会社中竜鉱業所
正会員永松勇

Isamu NAGAMATSU
を行なうなどで開発された。昭和 9 年に当社を設立し漸 次増産の一途をたどつたが，昭和 24 年に諸般の事情によ り一時休山し本格的な発展は昭和 26 年10月より始まる。 以後, 中山坑下部, 南仙翁坑, 人形坑上部において逐次 探鉱の成果が現われ，設備能力も昭和 35 年 $600 \mathrm{t} /$ 日, 昭 和39年 $1,050 t /$ 日, 昭和 41 年 $1,500 t /$ 日 と増強し現在に至 つている。

現状 : 現在, 中山坑, 南仙枌坑上部, 人形坑上部を出 